\title{
A Critique of the Militarisation of Australian History and Culture Thesis: The Case of Anzac Battlefield Tourism
}

\author{
Jim McKay, Centre for Critical and Cultural Studies, University of Queensland
}

This special issue on travel from Australia through a multidisciplinary lens is particularly apposite to the increasing popularity of Anzac battlefield tourism. Consider, for instance, the Dawn Service at Gallipoli in 2015, which will be the highlight of the commemoration of the Anzac Centenary between 2014 and 2018 (Anzac Centenary 2012). Australian battlefield tourism companies are already fully booked for this event, which is forecast to be 'the largest peacetime gathering of Australians outside of Australia' (Kelly 2011). Some academics have argued that rising participation in Anzac battlefield tours is symptomatic of a systemic and unrelenting militarisation of Australian history and culture. Historians Marilyn Lake, Mark McKenna and Henry Reynolds are arguably the most prominent proponents of this line of reasoning. According to McKenna:

\footnotetext{
It seems impossible to deny the broader militarisation of our history and culture: the surfeit of jingoistic military histories, the increasing tendency for military displays before football grand finals, the extension of the term Anzac to encompass firefighters and sporting champions, the professionally stage-managed event of the dawn service at Anzac Cove, the burgeoning popularity of battlefield tourism (particularly Gallipoli and the Kokoda Track), the ubiquitous newspaper supplements extolling the virtues of soldiers past and present, and the tendency of the media and both main political parties to view the death of the last World War I veterans as significant national moments. (2007)
}

In the opening passage of their book, What's Wrong With Anzac? The Militarisation of Australian History (henceforth, $W W W A$ ), to which McKenna contributed a chapter, Lake and Reynolds also avowed that militarisation was a pervasive and inexorable 
force: 'For several years now Australia has seen the relentless militarisation of our history; the commemoration of war and understanding of our national history have been conflated. The Anzac spirit is now said to animate all our past achievements, even as the Gallipoli Landing recedes into the distant past' (Lake \& Reynolds 2010a: vii). Lake (2010b: 12, 22) continued this theme in her introductory chapter by first stating that, 'Australian history has been thoroughly militarised,' and then foreshadowing that the book will examine the 'militarisation of Australian history, public memory and national values.' Some examples of militarisation presented in $W W W A$ are:

- the promotion of Anzac Day as the national day

- a resurgence of interest in Remembrance Day, VP Day, and Vietnam Veterans Day

- a profusion of newspaper articles, books and documentaries on military history

- obtuse and jingoistic behaviour by young Australian tourists at Gallipoli

- commemorations of WW1, WW2 and the Korean and Vietnam wars

- the advancement of Anzac by political leaders, the Department of Veterans' Affairs (DVA), the Australian War Memorial, the mass media and schools

- the attendance of former Prime Ministers Bob Hawke and John Howard at Dawn Services in Gallipoli.

Reactions to this militarisation thesis have ranged from effusive praise to anger in numerous academic and popular forums. ${ }^{1}$ It is unfeasible to untangle such a heated and multifarious controversy here, so I will focus on two aspects of militarisation that are relevant to this special issue. First, I argue that the version of militarisation proposed by Lake, McKenna and Reynolds contains ontological and epistemological flaws that render it incapable for understanding the multifaceted motivations for, and experiences of, Anzac battlefield tours. I then maintain that in order to study how Australians respond to Anzac battlefield tours researchers need to deploy an empirically grounded and multidisciplinary framework. As an alternative to the militarisation thesis, I draw on postmodern concepts of tourism to analyse instances of travel by high school students that problematise Anzac myths. ${ }^{2}$

\footnotetext{
${ }^{1}$ For strongly contrasting appraisals of both $W W W A$ and the larger so-called 'history wars' related to Anzac, see Bendle (2009, 2010a, 2010b, 2010c), Blainey (2010), Bryant (2010), McKernan (2010), O' Lincoln (2010), Prior (2010), Romei (2010) Shannon (2010) and The Age (2009).

2 I use 'myths' as formulated by Barthes in his classic text Mythologies (1973). For applications of Barthes's principles to Anzac, see Buchanan and James (1999), McKay (2010), Slade (2003) and White (2010). Hirst (1999), Macleod (2004a, 2004b, 2007) and Nile (1991b) adopted similar approaches in demythologising various aspects of Gallipoli.
} 


\section{Some ontological and epistemological flaws of the militarisation thesis}

In his seminal essay 'Notes on Deconstructing “The Popular,", Hall recommended that analyses of 'the popular' should always begin with 'the double stake in popular culture, the double movement of containment and resistance, which is always inevitably inside it' (1981: 228). He issued this advice because 'the people' invariably respond refractorily to attempts to govern them (current examples range from profuse 'leaderless' movements around the world modelled on 'Occupy Wall Street' to the series of insurrections in the Middle East). Consequently, Hall counselled scholars to examine the specific and multiple ways people ignore, recuperate, subvert and resist hegemonic discourses and practices. These vicissitudinous features are absent from the views of Lake, McKenna and Reynolds because of their restricted ontological and epistemological premises. Following the publication of Shaw's (1991) watershed analysis of postmilitarisation, scholars have investigated how military institutions both affect, and are affected by, other spheres - education, politics, sport, the economy, media, gender relations, family and civic life — by using carefully theorised empirical studies of the attitudinal, behavioural and discursive aspects of militarisation, remilitarisation and demilitarisation (Satana 2008; Sheffer \& Barak 2010). By contrast, Lake, McKenna and Reynolds neither define militarisation nor provide a theoretical framework for their arguments. This conceptual lacuna is their first step on a steep, slippery slope, whereby militarisation is assumed to be a fait accompli with the next move being to demonstrate its effects. Moreover, this presupposition is embedded in a top-down, monolithic, functionalist, and teleological polemic that rests mainly on anecdotal evidence.

Lake, McKenna and Reynolds focus predominantly on the public sphere: official ceremonies, media coverage, federal government expenditures and educational resources with allegedly militarising aims. Although this viewpoint identifies efforts by elites to legitimise their specific version of Anzac, it tells us little about informal reactions to official rhetoric and rituals. Historian Graeme Davison astutely highlights an important limitation of this top-down approach:

We historians, practitioners of 'history from below,' think 'downwards' from the nation to the intimate world of family and suburb, while the rest of the world thinks 'upwards,' only intermittently and sometimes unwillingly, from the private domain of home and family to the wider world. Historians seeking entry to the national soul have often dissected the public rituals of Australia Day and Anzac Day. They assume that public celebrations are a clue to private sentiments. (Davison 2003: 75) 
The closest we get to a bottom-up perspective is an aside by McKenna: 'the story of Anzac Day's resurgence should not only be understood from the top down. There appears to be a deep need on the part of many younger Australians for a shared sacred experience. A "moving" experience of what it means to be Australian. Anzac Day fills that need' (2007: 71). However, this both assumes that young Australians are 'cultural dopes' (Hall 1981: 230) and contains a functionalist premise about an experiential vacuum having to be satisfied. Davison identifies some obvious problems with this line of reasoning:

The trouble with the 'vacuum hypothesis' is that there are as many moral vacuums waiting to be filled as there are nostalgic historians ready to suggest them ... It doesn't explain why Anzac ... should be preferred to any other national or religious myth. (It's a theory that regards young people literally as suckers, ready to fill their inner emptiness with whatever mythology is on hand). Nor does it plausibly explain why, if we go by the attendance statistics, this mysterious vacuum has opened up so suddenly since the mid-1990s. (Davison 2003: 80)

Bottom-up perspectives that Lake, McKenna and Reynolds never consult reveal the recusant sort of scenario suggested by Hall regarding Australians' stances toward Anzac myths. In scrutinising the Australians and the Past survey (Hamilton \& Ashton 2003), Davison and fellow historian Richard White (2003) found that national anniversaries, holidays and commemorations are mediated in the main by familial and local networks with citizens manifesting sceptical, apathetic and even hostile attitudes toward official ceremonies (also see Clark 2012). In their studies of national identity, sociologists Timothy Phillips and Phillip Smith (Phillips \& Smith 2000; Smith \& Phillips 2001) ascertained that although Australians consistently endorsed Anzac motifs this was done relatively autonomously from discourses proffered by elites. These tenacious quotidian practices are evident with respect to Anzac Day, which, as historian Helen Robinson (2010: 77) put it, is 'not just a matter of attendance' but 'a question of attitude.' For instance, anthropologist Bruce Kapferer (1988) argued that Anzac Day has been characterised by a 'people-state opposition' with a cacophony of drinking, gambling, mateship, militarism, masculinity, disorder, liminality, communitas and tensions between authorities and citizens. ${ }^{3}$ Author and speechwriter Freudenberg has noted that such discordance over Anzac Day is even evident in $W W W A$ :

\footnotetext{
${ }^{3}$ Historian Ken Inglis, one of the most insightful analysts of Anzac, noted that Kapferer's ethnographic research needed to be qualified by a more subtle historical analysis of Anzac day practices (Inglis 1990; also see Inglis 2008).
} 
In their chapter on the anti-war movement, Carina Donaldson and Marilyn Lake write, 'The content over Anzac Day and then Vietnam (in the 1960s and 1970s) was part of a larger cultural struggle over the sort of society Australian should become.' That is, the Anzac debate can be productive and positive, by the authors' own standards. (Freudenberg 2010)

Ironically, Lake (2010b) noted such conflicting viewpoints among bloggers who responded to her criticisms of Anzac on The Age ('Creation' 2009) website: ‘[they] contained a mixture of hostility and support, personal attacks and thoughtful reflection ... there were as many contributors who expressed relief' (Lake 2010b: 4); 'rhapsodies [about Anzac] received short shrift from more cynical contributors to the debate who pointed to different history lessons' (5); 'the online forum attracted a lively, heated exchange that revealed ... deep divisions over the meaning of Anzac' (7). Lake also mentioned that some bloggers were inclined to invoke their family's military service as an entitlement to speak authoritatively and silence critics, but aside from wondering if the 'cult of Anzac' was producing 'two classes of citizens,' she again ignored what these responses might tell us about how intimate ties shape mundane interpretations of Anzac (Lake 2010b: 23). ${ }^{4}$

Similar problems arise with Lake's claims about the military history books: 'There are now more books published on Australians at war than ever before, hundreds during the last two decades alone. The shelves of bookshops groan under their weight and military history is usually given its own section of the shop' (2010b: 14). This personifies the loose and simplistic evidence used throughout $W W W A$. Shops do contain hagiographic Australian military history books, but also sell critical volumes like Zombie Myths of Australian Military History (Stockings 2010), The Broken Years (Gammage 2010), Gallipoli: The End of the Myth (Prior 2009), Zero Hour (Davidson 2010), All Day Long The Noise Of Battle (Windsor 2011) and, of course, WWWA. Two critical military history books were also acclaimed in the 2012 Prime Minister's Prize for Australian History. Paul Daley's (2009) Beersheba: A Journey through Australia's Forgotten War was shortlisted, and Bad Characters: Sex, Crime, Mutiny and Murder in the Great War by Peter Stanley (2010) was the joint winner. Moreover, we are not told how sales of books on Australian military history compare, for instance, with international bestselling ones by historians of World War Two, like Antony Beevor and Ian Kershaw. There is also no analysis of the motivations of, or the militaristic effects on, readers of military history texts.

\footnotetext{
${ }^{4}$ A similar pattern was also evident on two related blogs (Bryant 2010; Romei 2010).
} 
The declaration that 'we have seen the relentless militarisation of our history' would ostensibly warrant a thorough analysis of the organic intellectuals who currently research and teach military history in universities, but this is never done in $W W W A$, possibly because, contrary to the militarisation thesis, this field occupies a peripheral status in Australian education (Dean 2010). Lake also failed to note that highly critical material also appears in the popular media. Some examples are the three blogs mentioned above, newspaper articles by her and Reynolds (Lake 2009; Lake and Reynolds 2010b) and extended critiques by McKenna (2006a, 2007) and author and speechwriter Dennis Glover (2005) in two conservative national dailies. Critical appraisals of Anzac by journalists and academics also appear regularly in the flagship dailies of Fairfax Media in Melbourne and Sydney (Bantick 2010; McDonald 2011; Porter 2009; Prior \& Wilson 2002). The above ontological and epistemological flaws also shape how Lake, McKenna and Reynolds view Anzac battlefield tourism.

\section{Constructing moral panics and folk devils at Gallipoli}

In 2005 some young Australian tourists at Gallipoli on Anzac Day were described in the media as 'scumbags,' a 'blight on society' and 'the slobbering, filthy, unkempt Yobbo/Bogan Aussie backpacker' (Ziino 2006b). ${ }^{5}$ Such descriptions exemplify the observation by cultural geographer Rachel Hughes (2008: 319) that popular narratives of global travel are infused by a 'moral geography' with mobile postmodern tourists often portrayed as amoral citizens, especially at sites of remembrance. Like McKenna, Lake is similarly reproachful about young Australian tourists: 'Anzac Day [has] ceased to be a day of solemn remembrance and become a festive event, celebrated by backpackers wrapped in flags, playing rock music, drinking beer and proclaiming their national identity on the distant shores of Turkey' (Lake 2010b: 3).

In disagreeing with anthropologist and historian Clendinnen's (2006a) interpretation of Anzac Day, ${ }^{6}$ McKenna expressed despondence about 'feelgood flag-waving' at the 2005 Gallipoli Dawn Service:

I despair at the crass commercialisation of 25 April. Take the recent Anzac Day Dawn Services at Gallipoli, the voice of John Laws booming out over Anzac Cove as the Ode is read, rock videos playing, young Australians standing wrapped in the flag, stubbies in hand, beer bottles and waste strewn on the ground afterwards (is this the MCG or Anzac Cove?). To me, this cheap

\footnotetext{
${ }^{5}$ These are some descriptors documented by Ziino (2006b), who also notes there were defenders of young Australians.

${ }^{6}$ For a response to McKenna, see Clendinnen (2006b).
} 
choreography, much of it encouraged by the state, is not 'sober mourning' but an example of the new Australian patriotism - largely unreflective and blind to its political exploitation. (2006b: 70)

In his chapter in $W W W A$ McKenna (2010: 127) also disparaged young Australians at Anzac Cove for:

indulging in what [then-Prime Minister John] Howard called a 'rite of passage' ... providing the media with vox pops which suggested that the last thing on their minds was the history of WW1: 'It wasn't about the empire it was about us'; 'I am here because it's just great to be so proud of our history'; 'the diggers would be happy if they knew we were here'; 'they fought for us so that we could have a free life'; 'they're the reason we live the way we do.'

Analogous moralising also underpinned his co-authored article “'It's Really Moving Mate': The Gallipoli Pilgrimage and Sentimental Nationalism in Australia' (McKenna \& Ward 2007). The first part of the title came from a conversation McKenna and Ward initiated with a young Australian who was watching a World Cup football match involving Australia with a group of friends at a street-bar in Istanbul. His phrase about being stirred by a recent trip to Gallipoli was intended to convey their belief that it typified the emotional shallowness of such tourists. They also quoted an Australian newspaper article that condemned the behaviour of young Australians at the 2005 Gallipoli Dawn Service. The second section of their title was intended to communicate their critique of research at Gallipoli by historian Bruce Scates (2006). McKenna and Ward questioned aspects of Scates' methodology, including the purported 'danger' of using oral history: ' 'Unlike a primary source that is at arm's length, the personal and intimate nature of oral history makes it at once appear more convincing, more 'real,' harder to distance and harder to critique' (McKenna \& Ward 2007: 143). They then divined that: 'Much of Scates' language tells us that the book was written while he was under the emotional spell of his material ... Scates was entranced by the "landmarks of memory" ... and like many of the pilgrims he interviews ... caught up in the lure of Gallipoli as a sacred parable' (2007: 143-44).

Next, they asserted that experiences of pilgrimage documented by Scates needed 'to be understood primarily in the Australian context, not the local scenery at Gallipoli,' and offered the bemused reactions to Gallipoli by a group of Danish postgraduate students as attestation that Scates misconstrued the emotional responses of Australians (McKenna \& Ward 2007: 145). To bolster their case, they recommended the work of

\footnotetext{
${ }^{7}$ For a response to McKenna and Ward, see Scates (2007). For an apposite example of the rich insights obtained using the method of 'oral historiography,' see Clark (2012).
} 
two scholars as alternative readings of Australians' emotional responses at Gallipoli: sociologist Brad West (2005) and historian John McQuilton (2004). However, these suggestions confound their critique. They omitted that like any experienced ethnographer, West did not stay at 'arm's length' from the backpackers he studied; his research corroborated some of Scates' findings; and his dialogical and cosmopolitan framework is diametrically opposed to their teleological view. McQuilton incisively identifies some Australians' sense of entitlement about Gallipoli, but again McKenna and Ward leave out important insights by McQuilton that undermine their stance, such as 'Gallipoli has never had a single meaning,' 'Gallipoli has always been a contested space' and 'Gallipoli [is] contested space in terms of what people bring to it in the form of battlefield tours' (McQuilton 2004: 151). Furthermore, using anecdotal evidence to make broad and simple generalisations is evident once again: 'grabs' at one Dawn Service; quotes from a single newspaper article; the non-reactions of a few Danes; and a happenstance conversation with one person in a bar as verification that young Australian tourists manifest superficial emotions.

It is hardly surprising that a few boors are among the thousands of tourists whom the DVA controversially crams into a confined space with no reserved seating long before the Dawn Service at Gallipoli. Moreover, given both the liminality that Kapferer describes surrounding Anzac Day and that some young Australians are likely to have been on the global 'party tourism' circuit, the solemn behaviour of the vast majority of attendees is remarkable. Thus it is empirically unwarranted to use a few examples from a single Dawn Service and a one-off conversation at a bar to pillory young Australians when the overwhelming majority behaves civilly and respectfully on scores of battlefield tours every year.

In 1972 sociologist Stanley Cohen published Folk Devils and Moral Panics (2001), an analysis of skirmishes between 'mods' and 'rockers' at England seaside resorts. Cohen showed how mainly small frays and acts of vandalism were amplified by the media. These sensational representations, in turn, intensified public anxieties about allegedly declining morals and elicited demands for official intervention. Consequently, the police acted more vigorously in subsequent incidents, which led to additional arrests and a self-fulfilling prophecy about the dangers to society supposedly posed by these young people. To explain his findings Cohen devised a general model of 'moral panics' that is 
still used widely today. ${ }^{8}$ Historian Bart Ziino offered an explanation for media constructions of young Australians at Gallipoli in 2005 that is consistent with Cohen's concept of moral panics. Like McQuilton, he sees these portrayals as the most recent manifestation of Australians' recurring anxieties about 'ownership' of Gallipoli, in this case, 'fears about commercialisation of the sacred and its incursions on a particular memory of war' (Ziino 2006b: 8). In contrast to the teleological perspective of McKenna and Ward, Ziino explained pilgrimages and tourism at Gallipoli in a nuanced way:

Australians' relationships with Gallipoli are no longer mediated directly by the experience of the Great War, or the generation that experienced that trauma, but by a memory of war that is being recomposed constantly as Australians come into contact with the legend, the site from which it takes its origin, and a people who attach their own histories to this place. (Ziino 2006b: 8)

Lake opined that, 'As historians we think it is important to distinguish between history and mythology,' but she and McKenna turn myth-makers by constructing young Australians as 'folk devils' (2010a: 138). This aligns them with some awkward bedfellows: conservative politicians, journalists and Returned Service League (RSL) officials who are invariably deployed by media workers to vilify young Australians. 9 There is also a related paradox of McKenna criticising the media for its 'cheap choreography,' only to ventriloquise its reports in denouncing young Australians. ${ }^{10} \mathrm{I}$ next demonstrate the weaknesses of the militarisation thesis with respect to the teaching and learning of Anzac history in schools.

\section{Some classroom examples of deconstructing Anzac myths}

According to Lake the DVA has militarised history in schools during the past decade with students: 'conceptualised as the inheritors of the Anzac spirit and its custodians ... [and] ... bombarded in recent years and throughout the year with every aspect of our engagement in overseas wars' (2010b: 137). Lake also claimed that educational resources supplied by the DVA constitute 'a veritable tidal wave of military history ... [that] ... has engulfed our nation' (2010b: 135). She made this case on her reading of DVA materials, drawing selectively on another researcher's survey of schoolchildren and alluding to concerns of anonymous parents and teachers. The flaws in her

\footnotetext{
${ }^{8}$ For recent appraisals of Cohen's work, see Critcher (2009) and Jenkins (2009).

${ }^{9}$ McKernan (1998) and McQueen (2003) observe that radical Australian intellectuals have had a long-standing ambivalence toward Anzac myths.

${ }^{10}$ For examples of moral panics and Australian youth, see Poynting and Morgan (2007).
} 
methodology are readily apparent. ${ }^{11}$ First, like McKenna, she adopts a patronising 'cultural dope' view of teachers and students. Second, she neglects once again what can be learned from the Australians and the Past survey: 'we cannot assume that [information] is simply absorbed sponge-like by audiences. Schools, media, personalities, and politicians are the least trusted about the past ... Far more faith is placed in sources that are less likely to promote a singularly national past: in family anecdotes, or books' (White 2003: 56).

Third, teachers and students do not have messages about Anzac injected hypodermically into their brains so we need to know the various ways in which they engage with DVA resources. As we shall see, like all pedagogical materials, DVA items can be taught and learned in an array of ways: apathetically, cynically, enthusiastically, uncritically, reflectively and subversively. Yet Lake does not use conventional educational research methods (for example, in-depth interviews, ethnographies or analyses of 'formal,' 'hidden' and 'null' curricula) in a single classroom to investigate how teachers and learners handle DVA material. Without such research we cannot assume the pedagogical effects of any educational resources. As communication studies scholars Robert Hodge and Gunther Kress emphasised generically, 'Meaning is always negotiated in the semiotic process, never simply imposed inexorably from above by an omnipotent author through an absolute code' (1988: 12). Let us now consider some projects in which student have used military history and/or battlefield tours to construct alternative national practices based on healing, reconciliation and empathy.

When the Howard government was at its zenith, Adelaide schoolgirl Donna Handke was inspired by a fieldtrip to the village of Raukkan, formerly Point McLeay Aboriginal Mission, in the Coorong. The excursion was part of the Connecting Spirits project led by her national award-winning history teacher Julie Reece. The Ngarrindjeri regained control of Point McLeay in 1974 and in 1982 renamed it Raukkan ('A Place of Peace'). The majority of the village's approximately 125 residents are indigenous and its most renowned son is writer, inventor, preacher and political activist David Unaipon (18721967), who is commemorated by an image on the Australian $\$ 50$ note along with a picture of the Raukkan church. The church has a strong Anzac connection for the Ngarrindjeri: in 1925 a stained-glass window was installed in memory of five

${ }^{11}$ For a counter-critique of Lake by a contributor to the DVA resources, see Lewis (2010). 
Ngarrindjeri who died on the Western Front and in 1996 a memorial to them was also erected there. The soldiers needed permission from the Protector of Aborigines before they could leave Point McLeay and those who survived the war were subjected to his authority when they came back. The soldiers also fought and died for a country in which most indigenous people were not even entitled to vote for another five decades. A key promoter of the church memorial was the late Doreen Kartinyeri, niece of Private Rufus Rigney, one of 18 Aboriginal soldiers from Point McLeay whom she researched for her book Ngarrindjeri Anzacs (Kartinyeri 1996). Prior to her visit Handke never even knew that indigenous Australians had fought in WWI, but did a case-study of Rigney for a final year history project. She discovered that Rigney lied about his age so he could enlist with his older brother and uncle and was the only Ngarrindjeri with a marked grave on the Western Front. Handke and Reece then devised a plan to visit the cemetery in Belgium where Rigney was buried. After working part-time to raise funds for the trip, Handley and 12 other students commemorated Rigney's life and scattered sand from Ngarrindjeri country on his grave. The students returned with two items for the Ngarrindjeri: a video of the ceremony and soil from the gravesite that was used in a traditional ceremony for Rigney. Kartinyeri, who assisted Handke with her project, but had never met her uncles or seen Rigney's grave until she watched the video, said that: 'Here's a lovely young girl who has done something really worth while, not just for herself, but for us - blackfellas, Ngarrindjeri people. I can really say thank you, baby’ (Australian Broadcasting Corporation 2005).

In continuing the Connecting Spirits project, Reece returned to the cemetery with another group of her pupils and some Ngarrindjeri students from Meningie Area School, including relatives of Rigney. On Remembrance Day 2007, Reece and one of her pupils, Chloe Oborn, launched Connecting Spirits 2006 to document the excursion of the 22 students (Oborn \& Reece 2007). Scottish-Australian singer-songwriter Eric Bogle, whose And the Band Played Waltzing Matilda has often been used as an anti-war ballad, also performed for the first time Lost Soul, a song that was inspired by the Ngarrindjeri soldiers. Victor Koolmatrie, Rigney's great-nephew who performed a traditional tribute at his uncle's grave in Belgium, reflected that: 'It's about lost souls and we're trying to find them and commemorate them and tell the story about how the soldier is here and how he died. And so we're trying to connect our souls and their souls together' (Australian Broadcasting Corporation 2007). 
Among the worst atrocities perpetrated by the Japanese during WW2 were the Sandakan-Ranau POW death marches, which resulted in over 3,600 indigenous slavelabourers and 2,400 Allied soldiers dying and only six POWs - all Australianssurviving. In 2010 soil that students from Murwillumbah High School brought from Ranau and Sandakan POW camps was used at the opening ceremony of the Sandakan Memorial Walk adjacent to the local Cenotaph. The events at Sandakan, including research on the Walk, are also embedded in the school's Year 9 program (Goodman 2010). In 2011 Year 9 and 10 drama students at Toodyay District High School in rural Western Australia researched the Sandakan-Ranau POW death marches as part of their re-recording of the play, Six From Borneo (Simpson n. d.). This culminated in the launching of a CD that was attended by descendants of soldiers who died on the march and the Malaysian Consul General (Australian Broadcasting Corporation 2011b; The Australian Teacher 2011).

Melbourne students with diverse backgrounds from IŞIK (Turkish for 'illumination' or 'light') College and Penleigh and Essendon Grammar visited Gallipoli in 2010 in the spirit of friendship and intercultural understanding. The sentiments of Fatih Gezer from IŞIK pose an interesting challenge for the hypothesis that reactions to Gallipoli are predetermined by the Australian context: 'I'm on both sides because, you know, my homeland is Turkey and Australia. I spent most of my life in Australia so I'll be paying respect to both sides equally' (Australian Broadcasting Corporation 2010).

In 2011 students from the Hutchins School and St. Michael's Collegiate in Hobart, Rangitoto College in Auckland and Istanbul Lisesi began Tears of Gallipoli (2011) an exchange program designed to engender tolerance, understanding and reconciliation. As part of the program students from the four schools used the social media site Facebook to get acquainted. In March, sixteen Australian and New Zealand students stayed with families of the Istanbul students and travelled to Gallipoli with their Turkish counterparts where they attended the annual Martyrs' Day ceremony and visited battlefields. A month later the Hobart schools jointly hosted 10 Turkish students, who at the invitation of the Tasmanian RSL, marched in the Anzac Day parade and laid a wreath in Turkish colours at the main service (Australian Broadcasting Corporation 2011a, 2011c; Hoggett 2011; The Hutchins School 2011). According to John Devine, Head of International Exchanges at Hutchins, his students benefited from: 
an opportunity to see so many historical areas and places whilst they were over there - that was one thing they certainly commented about when they came back. They all were very moved when they went to Gallipoli and the way that it was phrased was almost in quiet awe. .... And they were surprised but extremely pleased with the great respect that any Turkish people they met showed them, whether it was Gallipoli or Istanbul or wherever they went. (Personal interview, 4 July 2011)

When I asked Vicki Paterson, a history teacher at St Michaels, who accompanied her students to Turkey and co-hosted the Turkish students with Hutchins, what her students learned from the exchange, she said that:

our girls said they got a greater understanding and appreciation of the Gallipoli story. They then mentioned the whole experience of being part of a family with a different cultural background and an entirely different way of living. They loved the experience of having a friend, having somebody they were living with who was in many ways very like them, they appreciated that camaraderie, that opportunity to be part of the family in an entirely different part of the world ... the Turkish students also said that they really enjoyed our Anzac Day service because it was a commemoration and they felt it was dignified and appropriate. Theirs is very military, planes flying over and rousing speeches, nationalistic speeches, whereas ours is ... a bit low key I suppose. (Personal interview, 6 July 2011)

In relating how St. Michael's teachers used DVA material, Paterson indicated that they had a 'very crowded curriculum' so used DVA resources 'sometimes but very, very sparingly ... mainly for its images.' When I asked if involving students in battlefield tours could glorify war, Paterson stated that:

We have had quite a deliberate attempt not to glorify war for some time. In fact, we have always questioned here the whole idea of the Anzac myth. We refer to it as myth and we look at that idea of mateship that's been heavily promoted by the government lately and we trace it back ... by looking at the growth of nationalism. We look at the whole outback, the drovers, where mateship really started and the art at the time that promoted nationalism and so on before we start to look at Gallipoli. And they look at the real causes for WW1 before they ... look at not just why the Gallipoli campaign took place from the point of view of Australia and Britain ... but from the point of view of Turkey and what was Germany's role and so on. (Personal interview, 6 July 2011)

Lake claims that 'Australian history has been thoroughly militarised.' However, all of the above projects engendered reconciliation, healing, tolerance and intercultural friendships, because students either studied military history, visited battlefields, attended commemorative military ceremonies, or in the case of the Connecting Spirits group, worked respectfully on military history projects with Aboriginal people. Lake and McKenna fail to grasp the polymorphous features of Anzac myths because their self-fulfilling assumptions rest on a top-down view of history, an overdetermined concept of militarisation and an oversocialised understanding of human behaviour (Gronow 2008; Wearing et al. 2009). From their omniscient viewpoint, it is always others who are deluded: young backpackers at Gallipoli who mindlessly channel John Howard; Scates and his respondents who mysteriously fall under the sacred spell of 
Gallipoli; and teachers and schoolchildren who passively absorb DVA material. Yet they do not present one in-depth account of what Australians have learned from visiting battlefields. Their assumptions that militarisation 'seems impossible to deny' and is 'relentless' means that - astonishingly for Professors of history - they even ignore how history students and teachers have both deconstructed Anzac myths and constructed alternative national practices. Perhaps the most ironic example of this blind spot is a winning essay in the 2010 Year 11/12 National History Challenge by Nicholas Peterson (2010) of Clarence Valley Anglican School in Grafton, NSW. The idea for his erudite and critical paper ('John Howard, Conservatism and the Celebration of ANZAC Day' [italics in original]) came from reading an article in Dissent by Lake (2007). These entwined ontological and epistemological defects also have important political consequences. Reynolds and Lake conclude $W W W A$ by rhetorically asking: 'The key premise of the Anzac legend is that nations and men are made in war. Is it not now time for Australia to cast it aside?' (2010: 167). However noble this goal might be, they offer no practical strategies regarding how to mobilise Australian citizens for this formidable utopian project ${ }^{12}$ and it is difficult to see how their plea will appeal to the enlightened students, teachers and tourists whom they variously silenced, patronised and demonised in $W W W A$. I now turn to an alternative framework for studying Anzac battlefield tourism by referring to empirical research on Anzac and some concepts that have been deployed in studies of postmodern tourism. My suggestions are not intended to be a 'blueprint' but a 'toolbox' of concepts that can be applied empirically to specific aspects of Anzac battlefield tourism.

\section{An alternative perspective on Anzac battlefield tourism}

Historian Humphrey McQueen observed that 'Anzac Day has never been what it used to be ... What continues to change are the cultural and political responses to the legacy of the Gallipoli campaign' (2003). We can see such dynamism in historical studies of pilgrimage, tourism and war. Peter Hoffenberg (2001) demonstrated how early pilgrimages to Gallipoli were shaped by a combination of events: travelling great distances; early reports on the condition of cemeteries by officials and former combatants; promotions by the Returned Sailors', Soldiers' and Airmen's Imperial League of Australia; and particular ways in which visitors imagined the landscapes of

\footnotetext{
${ }^{12}$ For some inherent contradictions of utopian intellectual projects see the work of contrarian philosopher John Gray $(2008,2009)$.
} 
both Australia and Gallipoli. In re-examining the research on tourism as a motivation for enlisting in WW1, Ziino (2006a: 52) revealed the intricacies of the nexus between war, tourism and home. He emphasised the 'duality' of the soldier-tourist identity and the 'multiple guises in which men and women understood their wartime experiences,' and contended that a 'tourist analogy' can help us to 'understand the cultural baggage that accompanied Australians to the war' (52). Davison's comment on the contingency of Anzac myths is also valuable here:

In 1989 it had seemed axiomatic that Anzac sentiment would be stronger while Anzacs were themselves there to represent and reinforce it and weaker once they died. Now we know what we should perhaps have realised from the beginning - that the myth might flourish even more luxuriantly when it was freed from the limitations of historical fact and the human frailties of its surviving representatives. Feeling connected to the past, after all, is not at all the same as being connected with history. (Davison 2003: 81)

In addition to the dynamic historical perspectives of Davison, Hoffenberg, McQueen and Ziino, we can also find contemporary evidence on tourism that directly contradicts the militarisation thesis. Based on responses to a questionnaire by hundreds of Australians who visited WW1 battlefields and cemeteries, Scates argued that even visitors with no direct connections to these sites could be classified as 'secular pilgrims.' Contrary to McKenna and Ward, Davison sees Scates's work as being useful in explaining the growing interest in Anzac among young Australians:

The key to understanding the power of myths, national or otherwise, lies in the intelligible connection they establish between personal experience and public events. When Australians were asked [in the Australians and the Past survey] about the most significant experiences in their own lives, the most frequently mentioned after the main life events — birth, childhood, marriage — were 'hardship' and 'holidays and travel.' Gallipoli connects powerfully to both, Bruce Scates has shown how strongly the pilgrimage to Gallipoli accommodates both the patriotism and the wanderlust of young Australians. (Davison 2003: 80-81)

Scates's findings have also been substantiated by other empirical studies. Clarke and Eastgate (2011) described the experiences of Australian tourists on the Western Front as a case of 'religion meets commemoration.' One study of Australians at Gallipoli by Hannaford and Newton (2008) and another of Australians and New Zealanders by Hyde and Harman (2011) also reported that participants manifested a combination of sacred and secular behaviours. Using ethnographic and semiotic methods West (2010) concluded that the genesis and development of memorialisation at Gallipoli was best explained by dialogical relationships among Australians, New Zealanders and Turks. West (2008b) also deployed aspects of globalisation, Bakhtin's notion of dialogical discourses and collective memory studies to analyse the experiences of Australian 
backpackers at Gallipoli. Drawing on his participant-observation and interviews, he reported that the ritual of 'international civil religious pilgrimage' engendered cosmopolitan interactions among Australians and Turks.

Lake posits that due to militarisation 'the rightful honouring of the dead and the writing of national history have been conflated' and that 'because war commemoration centres on timeless military virtues — "the Anzac spirit" ... all wars become one' (2010a: 12). Meanwhile ' $[\mathrm{h}]$ istorical specificity, difference and changing contexts are lost sight of' (12). These sweeping assertions are rebutted by empirical research. Historian Richard Braithwaite questioned the assumption that commercial tourism is inherently inappropriate at Sandakan by showing how it has assisted both residents and visitors to heal and reconcile with 'the past and former enemies' (Braithwaite \& Lee 2006). Braithwaite and Leiper found that a different situation existed at sites associated with the Thai-Burma Railway — 'recreation with a dash of lite infotainment' (2010: 327) and historian Kevin Blackburn (2000) reached similar conclusions about both the Railway sites and Changi Prison Museum. On the other hand, Blackburn (2001) found that regardless of whether visitors were veterans, relatives of the dead or tourists, they experienced the Changi Murals in terms of the sacred. In summary, tourists respond differently to different sites, because Anzac Cove is not the same as Chunuk Bair, Lone Pine and The Nek, and Gallipoli is different from Kokoda, Tobruk, Long Tan, Fromelles, the Australian War Memorial, the Shrine of Remembrance and the 16 Sandakan memorials around Australia. Like Anzac Day services, battlefield tourism needs to be viewed as a 'complex and ongoing negotiation of national and local histories in terms of local, regional and national identity politics' (Mayes 2009: 51). I now discuss some concepts that have been used productively in empirical studies of postmodern tourism, including battlefield sites.

Tourists do not travel just as they please. The pleasurable, nostalgic, romantic, hedonistic and fantastical experiences of tourists are enabled by a multibillion dollar global industry that is implicated in the commoditisation of mass murder, environmental degradation, sexual exploitation and social inequalities (Mosedale 2011; Seabrook 2001; Sturken 2007; Weaver 2011). Tourism is also mobilised for projects of social and civic governance (Bennett 2005; Pretes 2003). Yet these economic and political constraints do not operate in uncomplicated and unchallenged ways, because tourism 
both constitutes, and is constituted by, the broader context of postmodernity. I cannot investigate in detail numerous debates surrounding terms like postmodernism and postmodernity. ${ }^{13}$ However, Bauman's (1992, 1996a, 1996b, 2011) sociological perspective on 'liquid modernity' — whereby social identities and relations tend to be fluid, accelerated, contingent, disposable, and fragmented — is helpful for understanding the global dynamics of tourism, as is the 'coexistence thesis of detraditionalisation' proposed by Luke (1996) and Thompson (1996), who argued that ontological oppositions —old/new, past/present, traditional/modern and authentic/artificial—have become increasingly obsolete in mass-mediated societies where citizens constantly challenge and modify conventional beliefs and practices. This coexistence standpoint has obvious implications for understanding how tourists experience authenticity. For instance, Thompson asserts that 'traditions which rely heavily on mediated symbolic forms are not ipso facto less authentic than those which are transmitted through face-toface interaction ... the uprooting and re-mooring of traditions does not necessarily render them inauthentic' (Thompson 1996: 103).

Scholars have used these concepts to show how postmodern tourists bring repertoires of contradictory expectations and motivations to sites that can then be reinforced, challenged or transformed, depending on latent and manifest outcomes of tours. (Jansson 2007; Germann Molz 2010; Munt 1994). Whereas Lake and McKenna view tourists as shallow and sentimental dopes, empirical research shows that travellers have the capacity to engage reflexively with sites. For instance, postmodern tourists do more than passively gaze at other people, objects and locales; they also have embodied and mediated experiences that enable them to inhabit multiple, hybrid and fluid subjectivities (Edensor 2000; Månsson 2011; Urry \& Larsen 2011). Crouch and Desforges encapsulated this fluid and reflexive postmodern scenario in stating that, "the tourist is not only "a tourist" and draws upon complex significations in her/his practice of space through events and encounters' (2003: 10). This postmodern take on tourism means that authenticity needs to be analysed as a contingent combination of staged, existential, constructive and emergent experiences rather than dismissed as inherently amoral (Cohen \& Cohen 2012).

\footnotetext{
${ }^{13}$ For an overview see Featherstone (2007).
} 
This is evident in 'dark' tourism or 'thanotourism': you do not need not be Cambodian to be deeply affected by a visit to the Tuol Sleng Genocide Museum (Hughes 2008) or be Jewish to react sadly and respectfully to holocaust museums (Cohen 2011; Saindon 2012). Sociologist Jennifer Iles observed that battlefield tours have both 'constraints and opportunities that influence tourists' performances' (2006: 164). Thus tourists' reactions are affected by how their motivations and expectations interact with those of their fellow travellers, instructions of guides, behaviour of natives and a site's 'staged authenticity.' Consequently, battlefield tours can precipitate a range of often conflicting responses: guilt, revulsion, shame, anger, empathy, sorrow, comfort, pride, reverence, re-enchantment, empathy and communitas. Battlefield tourists can also challenge information provided by organisers and guides and transform their viewpoints (Muzaini et al. 2007). In their anthropological analysis of emotions at Gettysburg National Military Park, Gatewood and Cameron found that 'visitors sometimes began as tourists, but were transformed into pilgrims' (2004: 193). Similarly, one of Hannaford and Newton's visitors to Gallipoli stated that, 'I was a tourist in Istanbul but the moment we got anywhere near the site we were pilgrims' (2008). Likewise, young Australian backpackers can visit Gallipoli and reflect on the horror of war (Nile 1991a: 42). McKenna and Ward's teleological thesis that emotional experiences of young Australians need to be understood primarily in the Australian milieu, manifests a myopic understanding of the intricate interactions among tourists' reflexive abilities, global mobility, media technologies, cosmopolitan identities, nationalism, gender and generations (Allon et al. 2008; Hudson 2009; West 2006; 2008a). Regardless of the sentiments that Australian tourists bring to Gallipoli, they are both affected by, and influence, local events. Just one example is the admiration they develop for Turks after reading the empathetic message on the Atatürk Memorial bordering the entrance to Anzac Cove that Atatürk ('Father of the Turks') wrote in 1934:

Those heroes that shed their blood and lost their lives ... You are now lying in the soil of a friendly country. Therefore rest in peace. There is no difference between the Johnnies and the Mehmets to us where they lie side by side now here in this country of ours ... You, the mothers, who sent their sons from faraway countries wipe away your tears; your sons are now lying in our bosom and are in peace ... After having lost their lives on this land they have become our sons as well.

Lake and McKenna also ignore three consistent findings of empirical research on emotions and battlefield tourism: the co-existence of feelings of nationalism with sadness for the combatants and civilians who suffered on all sides; anger over the 
senselessness of warfare; and a desire for peace (Osbaldiston \& Petray, 2011).

McKenna (2007) expressed such contradictory emotions in stating that he was haunted by the courage of an Iraqi police officer who sacrificed his life to save people from dying in a suicide bomb attack. One could easily turn the emotional tables here- 'It's really haunting mate'-but his heartfelt response is similar to millions of people who see such events. And his afterthought—-The Anzac spirit is not uniquely Australian. It is universal' - is also shared by thousands of Australians and New Zealanders whose visits to Gallipoli have enabled them to see Gallipoli through the eyes of both Anzacs and Turks.

\section{Implications}

I have argued that Lake, McKenna and Reynolds have a procrustean view that is incapable of engaging with well-known articulations among tourism, commercialisation, embodiment and myriad technologies of memory, remembrance, and commemoration (Edwards 2009; Hirsch 2012; Keren 2009; Landsberg 2004; Sturken 1997; Todman 2009). As an alternative to their totalising view, I propose a multidisciplinary perspective that is capable of empirically investigating the particularities of postmodern tourism.

Both my critique and alternative are directly pertinent to the lead-up, implementation and consequences of the Anzac Centenary, which will be one of the biggest commemorative events in Australian history. Understanding the complex and contested ways in which Australians both at home and abroad will respond to this five-year commemoration is a daunting academic task, one unlikely to be achieved by a hotchpotch of anecdotes, moral condemnations, utopian rhetoric and preconceived ideas about the inescapable militarisation of Australian history and culture. While Lake and Reynolds (2010a: vii) opened $W W W A$ by claiming that the Gallipoli Landing was fading 'into the distant past,' both the composition and goals of the National Commission on the Commemoration of the Anzac Centenary were being criticised and controversies have surrounded the committee's subsequent activities (Dean 2010, 2011; Jones \& Tatnell 2012; Kelly 2011; Kelly \& Walters 2012; Shanahan 2012). Analysing such ongoing contestations at the both the micro and macro levels will require a rigorously empirical and multidisciplinary approach that is sensitive to the ways in which Australians constantly reconfigure Anzac myths. For as McKenna reminds us, albeit for 
reasons that he did not intend, 'There is always another Gallipoli waiting around the corner' (2006b: 70).

\section{Coda}

Gallipoli was a bastard of a place. I never understood what we were fighting for. All I could think of was that I never wanted to go back to the bloody place. (Gallipoli veteran Albert White, aged 100 in 1995; cited in Stephens 2001).

\section{Acknowledgements}

I would like to thank Dick Braithwaite, Helen Johnson, Matt Lamont, Catherine Palmer, Brian Petrie, Murray Phillips, Phillip Smith, Brad West, Richard White, two anonymous reviewers and Juliana de Nooy for their helpful comments on an earlier draft of this paper.

\section{Reference List}

Allon, F., Anderson, K. \& Bushell, R. 2008, 'Mutant Mobilities: Backpacker Tourism in "Global” Sydney,' Mobilities, vol. 3, no.1: 73-94.

Anzac Centenary. 2012, 'Anzac Centenary.' Online, available: http://www.anzaccentenary.gov.au/index.htm [Accessed 30 April, 2011].

Australian Broadcasting Corporation (ABC). 2005, 'One Service Charged with Extra Emotion,' 25 April. Online, available: www.abc.net.au/7.30/content/2005/s1353096.htm [Accessed 26 April 2005]. 2007, 'Lost Souls,' 9 November. Online, available: http://www.abc.net.au/stateline/sa/content/2006/s2088594.htm [Accessed 10 November 2007]. 2010, 'Back to Anzac Cove,' 26 April. Online, available: http://www.abc.net.au/7.30/content/2010/s2883092.htm [Accessed 27 April, 2010]. 2011 a, 'Lest We Forget: Tasmania Remembers,' 25 April. Online, available: lhttp://www.abc.net.au/news/stories/2011/04/25/3199851.htm [Accessed 26 April 2011]. 2011 b, 'Radio Archive Inspires Unique Education Project,' 16 September. Online, available: http://det.wa.edu.au/edenews/detcms/corporate-communications-marketing/ed-e-news/newsitems/september-2011/radio-archive-inspires-unique-education-project.en?oid=NewsItem-id11924364 [Accessed 17 September 2011]. 2011c, 'Young Turks to March in ANZAC Parade,' 24 April. Online, available: http://www.abc.net.au/news/video/2011/04/24/3199455.htm [Accessed 25 April 2011].

Bantick, C. 2010, 'What Lies Beneath a National Legend,' The Australian, 14 April. Online, available: http://www.theaustralian.com.au/in-depth/anzac-day/what-lies-beneath-a-national-legend/storye6frgdaf-1225857331747 [Accessed 15 April 2010].

Barthes, R. 1973, Mythologies, trans. A. Lavers. Paladin, London.

Bauman, Z. 1992, Intimations of Postmodernity. Routledge, London. 1996a, 'From Pilgrim to Tourist-Or a Short History of Identity,' in Questions of Cultural Identity, (eds) S. Hall \& P. du Gay. Sage, London: 18-36. 1996b, 'Morality in the Age of Contingency,' in Detraditionalization: Critical Reflections on Authority and Identity, (eds) P. Heelas, S. Lash, \& P. Morris. Blackwell, Oxford: 49-58. 2011, Culture in a Liquid Modern World. Polity Press, Cambridge.


available: http://www.quadrant.org.au/blogs/history-wars/2009/06/gallipoli-second-front-in-thehistory-wars [Accessed 30 June 2009]. 2010a, 'Anzac in Ashes,' Quadrant Online, April. Online, available: http://www.quadrant.org.au/magazine/issue/2010/4/anzac-in-ashes [Accessed 30 May 2010]. 2010b, 'The Assault on Anzac,' Quadrant Online, July-August. Online, available: http://www.quadrant.org.au/magazine/issue/2009/7-8/the-assault-on-anzac [Accessed 30 May 2010]. 2010c, 'Targeting the War Memorial,' Quadrant Online, May. Online, available: http://www.quadrant.org.au/blogs/history-wars/2010/05/targeting-the-war-museum [Accessed 30 May 2010]. 
Bennett, T. 2005, 'Civic Laboratories: Museums, Cultural Objecthood, and the Governance of the Social,' Cultural Studies, vol. 19, no. 5: 521-47.

Blackburn, K. 2000, 'Commemorating and Commodifying the Prisoner of War Experience in South-east Asia: The Creation of Changi Prison Museum,' Journal of the Australian War Memorial, no. 33. Online, available: http://www.awm.gov.au/journal/j33/blackburn.asp [Accessed 22 Feb 2010]. 2001, 'The Historic War Site of the Changi Murals: A Place for Pilgrimages and Tourism,' Journal of the Australian War Memorial, no. 34. Online, available: http://www.awm.gov.au/journal/j34/blackburn.asp [Accessed 22 February 2010].

Blainey, G. 2010, 'We Weren't That Dumb,' The Australian, 7 April. Online, available: http://www.theaustralian.com.au/news/arts/we-werent-that-dumb/story-e6frg8nf-1225848127735 [Accessed 7 April 2010].

Braithwaite, D. \& Lee, Y-L. 2006, 'Dark Tourism, Hate and Reconciliation: The Sandakan Experience,' International Institute for Peace Through Tourism Occasional Paper, no. 8, March. Online, available: http://www.iipt.org/educators/OccPap08.pdf [Accessed 2 February 2009].

Braithwaite, R. W. \& Leiper, N. 2010, 'Contests on the River Kwai: How a Wartime Tragedy Became a Recreational, Commercial and Nationalistic Plaything,' Current Issues in Tourism, vol. 13, no. 4: 311-32.

Buchanan, R. \& James, P. 1999, 'Lest We Forget,' Arena Magazine, no. 38, 25-30.

Bryant, N. 2010, 'What's Wrong with Anzac?' 24 April. Online, available: http://www.bbc.co.uk/blogs/thereporters/nickbryant/2010/04/whats_wrong_with_anzac.html [Accessed 29 April 2010].

Clark, A. 2012, 'Ordinary People's History,' History Australia, vol. 9, no. 1: 201-16.

Clarke, P. \& Eastgate, A. 2011, 'Cultural Capital, Life Course Perspectives and Western Front Battlefield Tours,' Journal of Tourism and Cultural Change, vol. 9, no. 1: 31-44.

Clendinnen, I. 2006a, 'The History Question: Who Owns the Past?,' Quarterly Essay, 23: 1-72. 2006b, 'The History Question: Response to Correspondence,' Quarterly Essay, 24: 77-87.

Cohen, E. \& Cohen, S. A. 2012, 'Authentication: Hot and Cool,' Annals of Tourism Research, vol. 39, no. 3: $1295-1314$.

Cohen, E. H. 2011, 'Educational Dark Tourism at an in populo Site: The Holocaust Museum in Jerusalem,' Annals of Tourism Research, vol. 38, no. 1: 520-39.

Cohen, S. 2001, Folk Devils and Moral Panics, $3^{\text {rd }}$ edition. Routledge, London.

Connecting Spirits. n.d., 'Connecting Spirits.' Online, available: http://connectingspirits.com.au/ [Accessed 12 Feb 2011].

'Creation of a Nation?' 2009, The Age website, 23 April. Online, available: http://blogs.theage.com.au/yoursay/archives/2009/04/creation_of a n.html?page=fullpage\#comme nts [Accessed 29 October 2009].

Critcher, C. 2009, 'Widening the Focus: Moral Panics as Moral Regulation,' British Journal of Criminology, vol. 49, no. 1: 17-34

Crouch, D. \& Desforges, L. 2003, 'The Sensuous in the Tourist Encounter: Introduction: The Power of the Body in Tourist Studies,' Tourist Studies, vol. 3, no. 1: 5-22.

Daley, P. 2009, Beersheba: A Journey Through Australia's Forgotten War. Pan Macmillan, Sydney.

Davidson, L. 2010, Zero Hour: The Anzacs on the Western Front. Penguin Group Australia, Camberwell, Vic.

Davison, G. 2003, 'The Habit of Commemoration and the Revival of Anzac Day,' Australian Cultural History, no. 23: 73-82.

Dean, P. 2010, 'Assessing and Reassessing Anzac in 2010.' Australian Policy \& History, September. Online, available: http://www.aph.org.au/files/articles/assessingReassessing.htm [Accessed 28 September 2010]. 2011, 'Education and the Centenary of Anzac,' Australian Policy \& History, May. Online, available: http://www.aph.org.au/files/articles/educationCentenary.htm [Accessed 29 May 2011].

Edensor, T. 2000, 'Staging Tourism: Tourists as Performers.' Annals of Tourism Research, vol. 27, no. 2 : 322-44.

Edwards, S. 2009, 'Commemoration and Consumption in Normandy, 1945-1994,' in War Memory and Popular Culture: Essays on Modes of Remembrance and Commemoration, (eds) M. Keren \& H. H. Herwig. McFarland \& \& Company, Jefferson, NC: 76-91.

Featherstone, M. 2007, Consumer Culture and Postmodernism. Sage, London.

Freudenberg, G. 2010, 'Lurching to the Rite,' The Walkley Magazine, 27 July. Online, available: http://www.walkleys.com/books/790/ [Accessed 28 July 2010]

Gammage, B. 2010, The Broken Years: Australian Soldiers in the Great War. Melbourne University Publishing, Melbourne. 
Gatewood J. B. \& Cameron, C. M. 2004, 'Battlefield Pilgrims at Gettysburg National Military Park,' Ethnology, vol. 43, no. 3: 193-216.

Germann Molz, J. 2010, 'Performing Global Geographies: Time, Space, Place and Pace in Narratives of Round-the-world Travel,' Tourism Geographies, vol. 12, no. 3: 329-48.

Glover, D. 2005, 'History of Forgetting,' The Weekend Financial Review, 22 April: 1-2, 8.

Goodman, R. 2010, 'Lost Spirits Laid to Rest in Walk,' Tweed Daily News, 16 August. Online, available: http://www.tweednews.com.au/story/2010/08/16/lost-spirits-laid-to-rest-in-walk/ [Accessed 16 August 2011].

Gronow, A. 2008, 'The Over- or the Undersocialized Conception of Man? Practice Theory and the Problem of Intersubjectivity.' Sociology, vol. 42, no. 2: 243-59.

Gray, J. 2008, Black Mass: Apocalyptic Religion and the Death of Utopia. Farrar, Straus and Giroux, New York. 2009, Gray's Anatomy. Allen Lane, London.

Hall, S. 1981, 'Notes on Deconstructing "The Popular,"” in People's History and Socialist Theory, (ed.) R. Samuel. Routledge \& Kegan Paul, London: 227-40.

Hamilton, P. \& Ashton, P. (eds) 2003, Australians and the Past. University of Queensland Press, St Lucia.

Hannaford, J. \& Newton, J. 2008, 'Sacrifice, Grief and the Sacred at the Contemporary "Secular" Pilgrimage to Gallipoli,' Borderlands, vol. 7, no. 1. Online, available: http://www.borderlands.net.au/vol7no1_2008/hannafordnewton_gallipoli.htm [Accessed 25 April 2011].

Hirsch, M. 2012, The Generation of Postmemory: Writing and Visual Culture After the Holocaust. Columbia University Press, New York.

Hirst, M. 1999, 'Narrative in the War Histories of C. E. W. Bean,' Access History, vol. 2, no. 2: 65-78. Online, available: www.uq.edu.au/access history/two two.html [Accessed 25 April 2010].

Hodge, R. \& Kress, G. 1988, Social Semiotics. Cornell University Press, Ithaca, NY.

Hoffenberg, P. H. 2001, 'Landscape, Memory and the Australian War Experience, 1915-1918,' Journal of Contemporary History, vol. 36, no.1: 111-31.

Hoggett, C. 2011, 'Turk Teens Help Forge Ties;' The Mercury, 26 April. Online, available: http://www.themercury.com.au/article/2011/04/26/225381 tasmania-news.html [Accessed 26 April, 2011].

Hudson, C. 2009, 'Embodied Spaces of Nation: Performing the National Trauma at Hellfire Pass,' Performance Paradigm, vol. 5, no. 2: 1-27. Online, available:

http://www.performanceparadigm.net/journal/issue-52/articles/embodied-spaces-of-nationperforming-the-national-trauma-at-hellfire-pass/ [Accessed 10 October 2011].

Hughes, R. 2008, 'Dutiful Tourism: Encountering the Cambodian Genocide,' Asia Pacific Viewpoint, vol. 49, no. 3: 318-30.

Hyde, K. H. \& Harman, S. 2011, 'Motives for a Secular Pilgrimage to the Gallipoli Battlefields,' Tourism Management, vol. 32, no. 6: 1343-51.

Iles, J. 2006, 'Recalling the Ghosts of War: Performing Tourism on the Battlefields of the Western Front,' Text and Performance Quarterly, vol. 26, no. 2: 162-80.

Inglis, K. S. 1990, 'Kapferer on Anzac and Australia,' Social Analysis, no. 29: 67-73. 2008, Sacred Places: War Memorials in the Australian Landscape, $3^{\text {rd }}$ edition, assisted by J. Brazier. Melbourne University Publishing, Carlton, Vic.

Jansson, A. 2007, 'A Sense of Tourism: New Media and the Dialectic of Encapsulation/Decapsulation,' Tourist Studies, vol. 7, no. 1: 5-24.

Jenkins, P. 2009, 'Failure to Launch: Why Do Some Issues Fail to Detonate Social Panics?' British Journal of Criminology, vol. 49, no. 1:35-47.

Jones, G. \& Tatnell, P. 2012, 'Furore over Image Branding of Anzac Centenary,' Herald Sun, 6 January. Online, available: http://www.heraldsun.com.au/news/more-news/fury-at-move-to-brand-anzacday/story-fn7x8me2-1226237820283 [Accessed 6 January 2012].

Kapferer, B. 1988, Legends of People, Myths of State: Violence, Intolerance, and Political Culture in Sri Lanka and Australia. Smithsonian Institution Press, Washington, DC.

Kartinyeri, D. 1996, Ngarrindjeri Anzacs. Aboriginal Family History Project, South Australian Museum and Raukkan Council, Adelaide.

Kelly, P. 2011, 'The Next Anzac Century,' The Australian, 23 April. Online, available: http://www.theaustralian.com.au/national-affairs/the-next-anzac-century/story-fn59niix1226043226240 [Accessed 23 April 2011].

Kelly, P. \& Walters, P. 2012, 'Disquiet for the Western Front Over Plans Honouring Centenary of Anzac,' The Australian, 7 July. Online, available: http://www.theaustralian.com.au/nationalaffairs/disquiet-for-the-western-front-over-plans-honouring-centenary-of-anzac/story-fn59niix- 
1226419219995 [Accessed 7 July 2012].

Keren, M. 2009, 'Introduction,' in War Memory and Popular Culture: Essays on Modes of Remembrance and Commemoration, (eds) M. Keren \& H. H. Herwig: McFarland \& Co., Jefferson, NC: 1-8.

Lake, M. 2007, 'Independent Histories,' Dissent, no. 23: 22-24. 2009, 'We Must Fight Free of Anzac, Lest We Forget Our Other Stories,' The Age, 24 April. Online, available: http://www.theage.com.au/opinion/we-must-fight-free-of-anzac-lest-we-forgetour-other-stories-20090422-afb7.html?page=-1 [Accessed 24 April, 2009]. 2010a, 'How do Schoolchildren Learn about the Spirit of Anzac?' In What's Wrong with Anzac? The Militarisation of Australian History, (eds) M. Lake \& H. Reynolds. New South Books, Sydney: 135-56. 2010b, 'Introduction: What Have You Done For Your Country?' In What's Wrong with Anzac? The Militarisation of Australian History, (eds) M. Lake \& H. Reynolds. New South Books, Sydney: 1-23.

Lake, M. \& Reynolds, H. 2010a, 'Preface,' in What's Wrong with Anzac? The Militarisation of Australian History, (eds) M. Lake \& H. Reynolds. New South Books, Sydney: vii-viii. 2010b, 'Letting go of Anzac,' The Age, 2 April. Online, available: http://www.theage.com.au/opinion/society-and-culture/letting-go-of-anzac-20100402-rif5.html [Accessed 2 April, 2010].

Landsberg, A. 2004, Prosthetic Memory: The Transformation of American Remembrance in the Age of Mass Culture. Columbia University Press, New York.

Lewis, R. 2010, 'Culture Warriors Against Anzac,' Quadrant Online, 25 April. Online, available: http://www.quadrant.org.au/blogs/history-wars/2010/04/robert-lewis [Accessed 16 April 2011].

Luke, T. W. 1996, 'Identity, Meaning and Globalization: Space-time Compression and the Political Economy of Everyday Life,' in Detraditionalization: Critical Reflections on Authority and Identity, (eds) P. Heelas, S. Lash \& P. Morris. Blackwell, Oxford: 109-33.

Macleod, J. 2004a, 'Introduction,' in Gallipoli: Making History, (eds) J. Macleod \& F. Cass, London: 113. 2004b, Reconsidering Gallipoli. Manchester University Press, Manchester. 2007, 'Beckham, Waugh and the Memory of Gallipoli,' in New Zealand's Great War: New Zealand, the Allies and the First World War, (eds) J. Crawford \& I. McGibbon. Exisle Publishing, Auckland: 142-56.

Månsson, M. 2011, 'Mediatized Tourism, 'Annals of Tourism Research, vol. 38, no. 4: 1634-52.

Mayes, R. 2009, 'Origins of the Anzac Dawn Ceremony: Spontaneity and Nationhood,' Journal of Australian Studies, vol. 33, no. 9: 51-65.

McDonald, H. 2011, 'Sticks and Stones Break Everyone's Bones,' The Sydney Morning Herald, 16 April. Online, available: http://www.smh.com.au/opinion/society-and-culture/sticks-and-stones-breakeveryones-bones-20110415-1dhpo.html [Accessed 16 April 2011].

McKay, J. 2010, 'Subterranean Currents in the ANZAC Myth and the Life Narrative of Ted Smout,' in Journeying and Journaling: Creative and Critical Meditations on Travel Writing, (eds) G. Basting, K. Douglas, M. McCrea \& M. X. Saves. Wakefield Press, Adelaide, SA: 189-203.

McKenna, M. 2006a, 'Comfort History,' The Australian, 18 March: 15. 2006b, 'The History Question: Correspondence,' Quarterly Essay, no. 24: 68-71. 2007, 'Patriot Act,' Australian Literary Review, 6 June. Online, available: http://www.theaustralian.news.com.au/story/0,20867,21813244-25132,00.html [Accessed 6 June 2011]. 2010, ‘Anzac Day: How Did It Become Australia's National Day?' In What's Wrong with Anzac? The Militarisation of Australian History, (eds) M. Lake \& H. Reynolds. New South Books, Sydney: 110-34.

McKenna, M. \& Ward, S. 2007, “'It's Really Moving Mate”: The Gallipoli Pilgrimage and Sentimental Nationalism in Australia,' Australian Historical Studies, no. 129: 141-51.

McKernan, M. 2010, 'Book Review,' History Cooperative, no. 99, November. Online, available: http://www.historycooperative.org/journals/lab/99/br_4.html [Accessed 6 November 2010]. 1998; 'Writing About War,' in Australia: Two Centuries of War and Peace, (eds) M. McKernan \& M. Browne. Australian War Memorial, Canberra: 11-24.

McQueen, H. 2003, 'Gallipoli's Shadows,' The Age, 25 April. Online, available: http://www.theage.com.au/articles/2003/04/25/1050777403378.html [Accessed 6 May 2010].

McQuilton, J. 2004, 'Gallipoli as Contested Commemorative Space,' in Gallipoli: Making History, (ed.) J. Macleod. Frank Cass, London: 150-58.

Mosedale, J. T. (ed.) 2011, Political Economy of Tourism: A Critical Perspective. Routledge, London. 
Munt, I. 1994, 'The “Other” Postmodern Tourism: Culture, Travel and the New Middle Classes,' Theory, Culture \& Society, vol. 11, no. 3: 101-23.

Muzaini, H., Teo, P. \& Yeoh, B. S. A. 2007, 'Intimations of Postmodernity in Dark Tourism: The Fate of History at Fort Siloso, Singapore,' Journal of Tourism and Cultural Change, vol. 5, no. 1: 28-45.

Nile, R. 1991a, 'Orientalism and the Origins of Anzac,' in Anzac: Meaning, Myth and Memory, (eds), A. Seymour \& R. Nile. University of London, Sir Robert Menzies Centre for Australian Studies, London: 32-42.

1991b, 'Peace, Unreliable Memory and the Necessities of Anzac Mythologies,' in Anzac: Meaning, Myth and Memory, (eds), A. Seymour \& R. Nile. University of London, Sir Robert Menzies Centre for Australian Studies, London: 79-91.

Oborn, C. \& Reece, J. 2007, Connecting Spirits 2006. Openbook Howden Design \& Print, Adelaide, SA.

O’ Lincoln, T. 2010, 'What's Wrong with Anzac?' Overland, 2 July. Online, available: http://web.overland.org.au/2010/07/non-fiction-review---what's-wrong-with-anzac/commentpage-1/ [Accessed 20 July 2010].

Osbaldiston, N. \& Petray, T. 2011, 'The Role of Horror and Dread in the Sacred Experience,' Tourist Studies, vol. 11, no. 2: 175-90.

Peterson, N. 2010, 'John Howard, Conservatism and the Celebration of ANZAC.' [Italics in original] Online, available: http://historychallenge.org.au/wp-content/uploads/2010/11/Year-Level-1112.pdf [Accessed 10 December 2010].

Phillips, T. \& Smith, P. 2000, 'What is “Australian"? Knowledge and Attitudes Among a Gallery of Contemporary Australians,' Australian Journal of Political Science, vol. 35, no. 2: 203-24.

Porter, L. 2009, 'Cry Anzac and Let Slip the Metaphors of War,' The Age, 19 April. Online, available: http://www.theage.com.au/opinion/cry-anzac-and-let-slip-the-metaphors-of-war-20090418aavc.html [Accessed 19 April 2009].

Poynting, S. \& Morgan, G. (eds) 2007, Outrageous! Moral Panics in Australia. ACYS Publishing, Hobart.

Pretes, M. 2003, 'Tourism and Nationalism,' Annals of Tourism Research, vol. 30, no. 1: 125-42.

Prior, R. 2009, Gallipoli: The End of the Myth. University of New South Wales Press, Sydney. 2010, 'Fighting on the Beaches. The Battle for Australian History,' Australian Book Review, 14 May: $12-14$.

Prior, R. \& Wilson, T. 2002, 'First Casualty,' The Sydney Morning Herald, 20 April. Online, available: http://www.smh.com.au/articles/2002/04/19/1019020708943.html [Accessed 20 April 2002].

Reynolds, H. \& Lake, M. 2010, 'Epilogue: Moving On?,' in What's Wrong with Anzac? The Militarisation of Australian History, (eds) M. Lake \& H. Reynolds. New South Books, Sydney: 157-67.

Robinson, H. 2010, 'Lest We Forget? The Fading of New Zealand War Commemorations, 1946-1966,' New Zealand Journal of History, vol. 44, no. 1: 76-91.

Romei, S. 2010, 'A Dig at the Diggers-What's Wrong With Anzac Day,' The Punch, 6 April. Online, available: http://www.thepunch.com.au/articles/a-dig-at-the-diggers-whats-wrong-with-anzac-day/ Accessed 7 April 2010].

Saindon, B. A. 2012, 'A Doubled Heterotopia: Shifting Spatial and Visual Symbolism in the Jewish Museum,' Quarterly Journal of Speech, vol. 98, no. 1: 24-48.

Scates, B. 2006, Return to Gallipoli: Walking the Battlefields of the Great War. Cambridge University Press, Cambridge.

2007, 'The First Casualty of War, A Reply to McKenna's and Ward's “Gallipoli Pilgrimage and Sentimental Nationalism,"' Australian Historical Studies, no. 130: 312-21. 2008, 'Transformation of the Turkish Military and the Path to Democracy,'Armed Forces \& Society, vol. 3, no. 3: 357-88.

Seabrook, J. 2001, Travels in the Skin Trade: Tourism and the Sex Industry, $2^{\text {nd }}$ edition. Pluto Press, London.

Shanahan, D. 2012, 'Approach to Dawn Service Needs Revision Before Anzac Centenary,' The Australian, 28 April. Online, available: http://www.theaustralian.com.au/news/nation/approach-todawn-service-needs-revision-before-anzac-centenary/story-e6frg6nf-1226341194283 [Accessed 28 April 2012].

Shannon, P. 2010, 'Dissenting Look at Militaristic Myth,' Green Left, 26 June. Online, available: http://www.greenleft.org.au/node/44555 [Accessed 29 June 2010].

Sharpley, R. \& Stone, P. R. (eds). 2009, The Darker Side of Travel: The Theory and Practice of Dark Tourism. Channel View Publications, Bristol.

Shaw, M. 1991, Post-Military Society: Militarism, Demilitarization and War at the End of the Twentieth Century. Polity, Cambridge. 
Sheffer, G., \& Barak, O. (eds) 2010, Militarism and Israeli Society. Indiana University Press, Bloomington, IN.

Simpson, C. n. d., 'Six From Borneo: The Story of the Death Marches and the Fate of the Prisoners of War in North Borneo.' Radio play, Australian Broadcasting Commission, Sydney.

Slade, P. 2003, 'Gallipoli Thanatourism: The Meaning of ANZAC,' Annals of Tourism Research, vol. 30, no. 4: 779-94.

Smith, P. \& Phillips, T. 2001, 'Popular Understandings of "UnAustralian”: An Investigation of the Unnational,' Journal of Sociology, vol. 37, no. 4: 323-39.

Stanley, P. 2010, Bad Characters: Sex, Crime, Mutiny, Murder and the Australian Imperial Force. Pier 9 , Millers Point, NSW.

Stephens, T. 2001, 'Last Anzac is Dead,' The Sydney Morning Herald, 17 May. Online, available: http://www.smh.com.au/articles/2002/05/16/1021544052449.html [Accessed 27 June 2010].

Stockings, C. (ed.) 2010, Zombie Myths of Australian Military History: The 10 Myths That Will Not Die. University of New South Wales Press, Sydney, NSW.

Sturken, M. 1997, Tangled Memories: The Vietnam War, the AIDS Epidemic, and the Politics of Remembering. University of California Press, Berkeley, CA. 2007, Tourists of History: Memory, Kitsch, and Consumerism from Oklahoma City to Ground Zero. Duke University Press, Durham, NC.

Tears of Gallipoli. 2011, 'Tears of Gallipoli.' Online, available: http://hauschundpartner.de/high_school/projekte-files/gallipoli_flyer_e.pdf [Accessed 25 April 2011].

The Australian Teacher. 2011, 'Toodyay Kids Bring POW Stories to Life,' November. Online, available: http://ozteacher.com.au/html/index.php?option=com_content\&view=article\&id=1497:toodyaykids-bring-pow-stories-to-life\&catid=3:classroom-news\&Itemid=66 [Accessed 20 November 2011].

The Hutchins School. 2001, 'ANZAC Spirit in Hutchins Turkish Exchange,' 5 May. Online, available: http://www.hutchins.tas.edu.au/news-and-events/?item=44 [Accessed 25 April 2011].

Thompson, J. B. 1996, 'Tradition and Self in a Mediated World,' in Detraditionalization: Critical Reflections on Authority and Identity, (eds) P. Heelas, S. Lash, \& P. Morris. Blackwell, Oxford: 89-108.

Todman, D. 2009, 'The Ninetieth Anniversary of the Battle of the Somme,' in War Memory and Popular Culture: Essays on Modes of Remembrance and Commemoration, (ed.) M. Keren \& H. H. Herwig. McFarland \& Company, Jefferson, NC: 22-40.

Urry, J., \& Larsen, J. 2011, The Tourist Gaze 3.0. Sage, London.

Wearing, S. L., Wearing, M. \& McDonald, M. 2009, 'Understanding Local Power and Interactional Processes in Sustainable Tourism: Exploring Village-Tour Operator Relations on the Kokoda Track, Papua New Guinea,' Journal of Sustainable Tourism, vol. 8, no. 1: 61-76.

Weaver, A. 2011, 'Tourism and the Military: Pleasure and the War Economy,' Annals of Tourism Research, vol. 38, no. 2: 672-89.

West, B. (ed.) 2005, Down the Road: Exploring Backpacker and Independent Travel. API Press, Perth. 2006, 'Consuming National Themed Environments Abroad: Australian Working Holidaymakers and Symbolic National Identity in Aussie theme pubs,' Tourist Studies, vol 6, no. 2: 139-55. 2008a, 'Collective Memory and Crisis: The 2002 Bali Bombing, National Heroic Archetypes and the Counter-narrative of Cosmopolitan Nationalism,' Journal of Sociology, vol. 44, no. 4: 337-53. 2008b, 'Enchanting Pasts: The Role of International Civil Religious Pilgrimage in Reimagining National Collective Memory,' Sociological Theory, vol. 26, no. 3: 258-70. 2010, 'Dialogical Memorialization, International Travel and the Gallipoli Battlefields,' Tourist Studies, vol. 10, no. 3: 209-26.

White, L. 2010, 'ANZAC Day and Nationalism: The Sacred Place of this "One Day of the Year" in Contemporary Australia,' in Reflections on Anzac Day: From One Millennium To The Next, (eds) A-M. Hede and R. Rentschler. Heidelberg Press, Heidelberg, Vic.: 31-46.

White, R. 2003, 'National Days and the National Past in Australia,' Australian Cultural History, no. 23 : 55-72.

Windsor, G. 2011, All Day Long The Noise Of Battle. Pier 9, Millers Point, NSW.

Ziino, B. 2006a, 'A Kind of Round Trip: Australian Soldiers and the Tourist Analogy, 1914-18,' War \& Society, vol. 25, no. 2: 39-52.

2006b, 'Who Owns Gallipoli? Australia's Gallipoli Anxieties, 1915-2005,' Journal of Australian Studies, no. 88: 1-12. 